\title{
RECURRENT SELECTION IN INBRED POPCORN FAMILIES
}

\author{
Máskio Daros ${ }^{1}$; Antônio Teixeira do Amaral Jr. ${ }^{1 *}$; Messias Gonzaga Pereira ${ }^{1}$; Fabrício Santana \\ Santos $^{1}$; Ana Paula Cândido Gabriel ${ }^{1}$; Carlos Alberto Scapim²; Silvério de Paiva Freitas Jr. ${ }^{1}$; \\ Lucas Silvério ${ }^{2}$ \\ ${ }^{I}$ UENF - Lab. de Melhoramento Genético Vegetal - Av. Alberto Lamego, 2000, Parque Califórnia - 28013-600 - \\ Campos dos Goytacazes, RJ - Brasil. \\ ${ }^{2}$ UEM - Depto. de Agronomia, 8702-900 - Maringá, PR - Brasil. \\ * Corresponding author <amaraljr@uenf.br>
}

\begin{abstract}
Although much appreciated in Brazil, commercial popcorn is currently cropped on a fairly small scale. A number of problems need to be solved to increase production, notably the obtaintion of seeds with good agronomic traits and good culinary characteristics. With the objective of developing superior genotypes in popcorn, a second cycle of intrapopulation recurrent selection based on inbred $\mathrm{S}_{1}$ families was carried out. From the first cycle of selection over the UNB-2U population, $222 \mathrm{~S}_{1}$ families were obtained, which were then divided into six sets and evaluated in a randomized complete block design with two replications within the sets. Experiments were carried out in two Brazilian localities. The analysis of variance revealed environmental effects for all evaluated traits, except popping and stand, showing that, for most traits, these environments affected genotype behavior in different ways. In addition, the set as source of variation was significant for most of the evaluated traits, indicating that dividing the families into sets was an efficient strategy. Genotype-by-environment interaction was detected for most traits, except popping expansion and stand. Differences among genotypes were also detected ( $1 \%$ F-test), making viable the proposition of using the genetic variability in the popcorn population as a basis for future recurrent selection cycles. Superior families were selected using the Smith and Hazel classic index, with predicted genetic gains of $17.8 \%$ for popping expansion and $26.95 \%$ for yield.
\end{abstract}

Key words: breeding program, $\mathrm{S}_{1}$ families, yield, popping expansion

\section{SELEÇÃO RECORRENTE EM FAMÍLIAS ENDOGÂMICAS EM MILHO PIPOCA}

\begin{abstract}
RESUMO: Embora muito apreciada no Brasil, o milho pipoca comercial é normalmente cultivado em pequena escala. Para aumentar a produção, alguns problemas precisam ser resolvidos, principalmente a obtenção de sementes com boas características agronômicas e culinárias. Com o objetivo de obter genótipos superiores de milho pipoca, foi conduzido um segundo ciclo de seleção recorrente intrapopulacional, com base em famílias endogâmicas $S_{1}$. Duzentas e vinte e duas famílias $S_{1}$ foram obtidas a partir do ciclo 1 da população UNB-2U e foram avaliadas em delineamento de blocos casualizados com duas repetições dentro de 'sets', em dois locais no Brasil. A presença de significância estatística para 'sets' para as características número de espigas doentes e sadias, capacidade de expansão, número de plantas quebradas e número de espigas mal empalhadas, comprova a eficiência e a necessidade do uso de modelo estatístico hierarquizado por 'sets'. Constatou-se significância ( $1 \%$ teste F), para famílias dentro de 'sets', revelando suficiente variabilidade genética a ser explorada em ciclos futuros, essencial para o sucesso do programa. A seleção das famílias superiores, realizada com base no Índice Clássico de Smith e Hazel, proporcionou ganhos preditos de 17,8\% para capacidade de expansão e de $26,95 \%$ para produção de grãos.

Palavras-chave: programa de melhoramento, famílias $\mathrm{S}_{1}$, rendimento e capacidade de expansão
\end{abstract}

\section{INTRODUCTION}

Although much appreciated in Brazil, commercial popcorn is currently cropped on a fairly small scale (Andrade, 1996; Linares, 1987; Zanette, 1989). A number of problems need to be solved to increase production, notably the obtaintion of seeds with good agronomic traits (Pacheco et al., 1998) and good culinary characteristics, especially popping (Gama et al., 1990; Pereira \& Amaral
Jr., 2001). Few breeding studies have been carried out on the crop, with the result that the popcorn commercially available in Brazil is of poor quality (Andrade, 1996). This is why $75 \%$ of the popcorn consumed in Brazil is imported (Galvão et al., 2000).

The intrinsic value of the grain in a quantity of popcorn equivalent to US\$1 is about US\$ 0.01 (Whittell, 2002). The predicted profit is therefore equivalent to $10,000 \%$, so it is essential to develop research in Brazil 
to improve the country's production:consumption ratio. Over the years, the importance of introducing improved popcorn cultivars and superior hybrids has been demonstrated in Brazil. To make this point, Linares (1987) cites the example of the USA, where popping maize production increased from 24,000 to $2,560,000$ tons in 37 years (1934 to 1971). Yield figures kept pace with this increase, going from $1.8 \mathrm{t} \mathrm{ha}^{-1}$ in 1920 to $3.3 \mathrm{t} \mathrm{ha}^{-1}$ in 1973 . Releasing new cultivars onto the national market will significantly stimulate production in Brazil. Turnover in the USA alone is currently around 1.155 billion dollars annually (Pacheco et al., 1998; Galvão et al., 2000).

Popcorn breeding programs are under way at a number of locations in Brazil, including Viçosa and Sete Lagoas (Minas Gerais State), Maringá and Londrina (Paraná State), and Piracicaba and Campinas (São Paulo State). A popcorn breeding program at Campos dos Goytacazes has also been developed, aimed at releasing varieties with characteristics tailored for cultivation in the north and northwest regions of Rio de Janeiro State.

The initial program stages involved assessing the potential of the UNB-2U population and identifying more efficient breeding strategies to produce improved varieties (Pereira \& Amaral Jr., 2001). The first recurrent selection cycle based on full-sib family selection resulted in predicted gains of $4.69 \%$ (yield) and $10.39 \%$ (popping expansion) (Daros et al., 2002). In the second cycle, recurrent selection based on $\mathrm{S}_{1}$ families was thought more appropriate, and was the second-best strategy in terms of gains achieved with UNB-2U (Pereira \& Amaral Jr., 2001).

Selection based on inbred family performance has been successfully used to increase yield in popping maize populations. For example, using direct selection on $S_{1}$ progeny at Viçosa, Vilarinho (2001) obtained gains of $1.08 \mathrm{~mL} \mathrm{~g}^{-1}$ (popping expansion) and $12.97 \mathrm{~kg} \mathrm{ha}^{-1}$ (grain yield) for the second recurrent selection cycle in inbred families, even with an estimated genotypic correlation of -0.39 between the two traits.

This study was intended as a continuation of the popcorn breeding program at the Universidade Estadual do Norte Fluminense Darcy Ribeiro (Rio de Janeiro State, Brazil), with selection of $S_{1}$ families derived from the UNB-2U cycle 1 population. Expectations for the near future include the possible release an improved variety with high commercial value for the north and northwest regions of Rio de Janeiro State.

\section{MATERIAL AND METHODS}

The UNB-2U cycle 1 population (UNB-2U-C1) was subjected to intrapopulation recurrent selection based on inbred families $\left(\mathrm{S}_{1}\right)$. The first cycle was based on fullsib recurrent selection (Daros et al., 2002). Two hundred and twenty-two $S_{1}$ families were obtained. Some of the seeds from each family were stored for later assessment and some subjected to evaluation tests. The tests were run in December 2001 in Campos do Goytacazes (21 $45^{\prime} 15^{\prime}$ " $\mathrm{S}, 41^{\circ} 19^{\prime} 28^{\prime \prime}$ W) (northern region of Rio de Janeiro State) and in January 2002 in Itaocara (21 $40^{\prime} 09^{\prime \prime}$ S, 42 $04^{\circ} 34^{\prime \prime}$ W), (northwest region of Rio de Janeiro State).

A randomized complete block design was used, with two replications in six sets, each consisting of 37 families and five controls. Each family was cultivated in a $5.0 \mathrm{~m}$ row with inter-row spacing of $1.0 \mathrm{~m}$ and $0.2 \mathrm{~m}$ spacing between plants. Initially, fifty seeds were sown per row. One month after sowing, the plants were thinned to 25 plants per row. Soil preparation, fertilizer application and cultural practices were in compliance with the recommendations (EMBRAPA, 1993; Fancelli \& Dourado Neto, 2000).

The following traits were evaluated: a) stand (ST) - number of plants in the row; b) broken plants (BP) number of plants with the stem broken below the upper ear at harvest; c) poorly hulled ears (PHE) - number of ears not completely covered by husk; d) number of ears (NE) - ears harvested in each plot; e) number of diseased ears (NDE) - number of diseased ears harvested in the plot; f) grain yield (GY) - weight of grain in $\mathrm{kg} \mathrm{ha}^{-1}$; g) popping expansion (PE).

Popping expansion was assessed in a popcorn machine developed by Embrapa/Instrumentação Agropecuária, incorporating an electronic resistor and thermostat. Two 30-mL grain samples were obtained from each plot. After pre-heating the machine to $270^{\circ} \mathrm{C}$, each sample was cooked for 2.5 minutes. Expanded volume was measured in a $1000 \mathrm{ml}$ graded test tube. Popping expansion was calculated as the ratio of expanded volume to initial volume.

Variance analysis was carried out on the traits measured, based on the randomized complete block design, with two replications within sets in two environments according to the genetic-statistical model proposed by Hallauer \& Miranda Filho (1981), ie: $\mathrm{Y}_{\mathrm{i} \mathrm{jkl}}=\mu$ $+E_{\mathrm{i}}+\mathrm{S}_{\mathrm{j}}+\mathrm{ES}_{\mathrm{ij}}+\mathrm{R} / \mathrm{ES}_{\mathrm{ijk}}+\mathrm{F} / \mathrm{S}_{\mathrm{j} 1}+\mathrm{EF} / \mathrm{S}_{\mathrm{ijl}}+\xi_{\mathrm{ijk} \mathrm{l}}$, where $\mu$ is the general mean; $E_{i}$ is the fixed effect of the $i^{\text {th }}$ environment; $S_{j}$ is the effect of the $j^{\text {th }}$ set; ES $_{\mathrm{ij}}$ is the effect of environment-by-set interaction; $\mathrm{R}^{\mathrm{ES}} \mathrm{ES}_{\mathrm{ijk}}{ }_{\mathrm{ij}}$ is the effect of the $\mathrm{k}^{\text {th }}$ replication within the environment-by-set interaction; $F / S_{j 1}$ is the effect of the $1^{\text {th }}$ family within the set; $\mathrm{EF} / \mathrm{S}_{\mathrm{ijl}}$ is the effect of the environment-by-family interaction within the set; and $\xi_{\mathrm{ijk} l}$ is the experimental error.

Each set was analyzed separately and then the results from the six sets were grouped for each environment. Finally, the results for all sets were combined for the two environments. All sources of variation, with the exception of environment, were assumed to be random. The SAS Program (SAS, 1985) was used for data analysis. 
The genetic parameters, phenotypic $\left(\sigma_{f}^{2}\right)$ and genotypic $\left(\sigma_{g}^{2}\right)$ variance and heritability on the family mean basis $\left(h^{2}\right)$ were estimated as follows: $\sigma_{f}^{2}=\frac{M S F}{r e}$; $\sigma_{g}^{2}=\frac{M S F-M S E}{r e}$; and $h^{2}=\frac{\sigma_{g}^{2}}{\sigma_{f}^{2}}$; where: MSF and MSE are respectively the family meán square and error mean square; $\mathbf{r}$ is the number of replications; $\mathbf{e}$ is the number of environments.

Superior progenies were selected, based on the Smith (1936) and Hazel (1943) classic index and using the Genes computer program (Cruz, 2001) to compute the solution to matrix system $\mathbf{b}=\mathbf{P}^{-1} \mathbf{G a}$, where $\mathbf{b}$ is the dimension vector $7 \times 1$ of the weighting coefficients of the index, $\mathbf{P}^{-1}$ is inverse of the $7 \times 7$ dimension matrix of phenotypic covariance among the traits, $\mathbf{G}$ is the $7 \times 7$ dimension matrix of genotypic covariance among the traits and $\mathbf{a}$ the economic weights. The following values were attributed as economic weights: number of diseased ears $(-20)$, popping $(1,200)$, stand $(10)$, broken plants $(-20)$, number of poorly hulled ears (-550), number of ears (20) and grain weight (40). The weights were defined by observing the most favorable gains for grain yield and popping expansion, as well as gains for other desirable traits. A total of forty progenies were selected to make up the recombination batch and form the second cycle population (UNB-2U C2) using the $\mathrm{S}_{1}$ seeds placed in storage.

\section{RESULTS AND DISCUSSION}

The coefficient of variation for the seven evaluated traits was considered high for all traits, except stand and popping expansion (Table 1). Coimbra (2000) also reported coefficient of variation values considered very high for some traits in popcorn, such as proportion of bro- ken plants, proportion of lodged plants, weight of diseased ears, poorly hulled ears and plants attacked by fall armyworm. According to the author, the high values of the coefficients are compatible with those observed in other studies for this crop. The relatively high value for the grain yield coefficient of variation may be attributed to the size of plot used (one row plot), as well as the type of progeny. Inbred progenies are usually more sensitive to environmental effects presenting relatively high residual variance. Despite this, considering the high proportion of genetic variance between $S_{1}$ families $\left(\sigma_{A}^{2}+\right.$ $0.25 \sigma_{D}^{2}$ ), the most effective method is to select the best families on the basis of grain yield and other traits.

The results of popcorn half-sib progeny selection analyzed by Pacheco et al. (1998), also reported CV (\%) values for percentage of lodged and broken plants of $156.40 \%$ and $50.50 \%$, respectively, for the CMS-42 population. For the CMS-43 population, the respective CV (\%) values for percentage of lodged and broken plants were $143.80 \%$ and $59.30 \%$. The analysis of variance results indicate environmental effects for the evaluated traits, except popping and stand (Table 1), showing that the environments differed sufficiently to affect most of the evaluated traits.

One of the problems frequently faced in field experiments is plant failure. This affects the stand and makes it difficult to compare the treatments (Coimbra, 2000). In our experiments, the stand varied from 9 to 25 plants per plot. The stand variance analysis figures (Table 1) show that the variation source families were significant within sets $\left(\mathrm{F} / \mathrm{S}_{\mathrm{j}}\right)$, with a $1 \%$ probability in the $\mathrm{F}$ test. Therefore, no correction for stand was made since this would not have been a suitable procedure for the

Table 1 - Mean squares, general mean, maximum and minimum family mean values and coefficients of variation of the seven evaluated traits in the $S_{1}$ families.

\begin{tabular}{|c|c|c|c|c|c|c|c|c|}
\hline \multirow{2}{*}{ Source $^{2 /}$} & \multirow{2}{*}{ DF } & \multicolumn{7}{|c|}{$\mathrm{MS}^{1 /}$} \\
\hline & & NDE & $\mathrm{PE}$ & $\mathrm{ST}$ & BP & PHE & $\mathrm{NE}$ & GY \\
\hline $\mathrm{E}$ & 1 & $1377.41 * *$ & $3.64 \mathrm{~ns}$ & $09.89 \mathrm{~ns}$ & $3142.01 * *$ & $1104.99 * *$ & $4391.94 * *$ & $605672.21 * *$ \\
\hline S & 5 & $128.94 * *$ & $29.07 * *$ & $03.12 \mathrm{~ns}$ & $31.54 *$ & $25.41 * *$ & $104.20 * *$ & $22824.24 \mathrm{~ns}$ \\
\hline $\mathrm{E} \times \mathrm{S}$ & 5 & $113.27 * *$ & $30.80 * *$ & $42.91 * *$ & $48.05 * *$ & $30.71 * *$ & $54.27 \mathrm{~ns}$ & $139981.16 * *$ \\
\hline $\mathrm{R} / \mathrm{E} \times \mathrm{S}$ & 12 & $20.57 \mathrm{~ns}$ & $3.92 \mathrm{~ns}$ & $08.66 \mathrm{~ns}$ & $05.08 \mathrm{~ns}$ & $8.40 \mathrm{~ns}$ & $44.65 \mathrm{~ns}$ & $36580.74 * *$ \\
\hline $\mathrm{F} / \mathrm{S}$ & 216 & $42.27 * *$ & $32.24 * *$ & $09.34 * *$ & $34.22 * *$ & $12.94 * *$ & $114.32 * *$ & $101807.35 * *$ \\
\hline $\mathrm{E} \times \mathrm{F} / \mathrm{S}$ & 216 & $29.83 *$ & $6.48 \mathrm{~ns}$ & $04.96 \mathrm{~ns}$ & $17.39 * *$ & $9.69 * *$ & $63.62 * *$ & $41247.97 * *$ \\
\hline Error & 432 & 23.73 & 5.51 & 05.07 & 10.98 & 4.74 & 26.44 & 16139.40 \\
\hline Maximum & & 42.00 & 25.00 & 34.00 & 23.00 & 23.00 & 51.00 & 1440.00 \\
\hline Average & & 8.84 & 13.28 & 22.85 & 07.55 & 1.76 & 19.80 & 370.10 \\
\hline Minimum & & 0.00 & 3.83 & 09.00 & 00.00 & 0.00 & 2.00 & 7.00 \\
\hline $\mathrm{CV}(\%)$ & & 55.10 & 17.68 & 09.85 & 43.86 & 123.11 & 25.97 & 34.32 \\
\hline
\end{tabular}

${ }^{1 / \mathrm{NDE}}=$ number of diseased ears; $\mathrm{PE}=$ popping expansion; $\mathrm{ST}=$ stand; $\mathrm{BP}=$ broken plants; PHE = poorly hulled ears; NE = number of ears; $\mathrm{GY}=$ grain yield in $\mathrm{kg} \mathrm{ha}^{-1}$.

${ }^{2 /} \mathrm{E}=$ Environments; $\mathrm{S}=$ Sets; $\mathrm{R}=$ Replications; $\mathrm{F}=$ Families.

$* *$, * significant by $\mathrm{F}$-testing at $1 \%$ and $5 \%$, respectively.

Sci. Agric. (Piracicaba, Braz.), v.61, n.6, p.609-614, Nov./Dec. 2004 
present data set. Variations in stand figures here were probably genetic in origin, as opposed to environmental, in the absence of significant environmental effects for the trait.

Except for number of ears, the other traits presented significant set-by-environment interaction figures (Table 1), indicating that genotype-by-environment interaction was significant. This was confirmed for most traits by the significance of the ExF/S figure (Table 1).

The prospects for successfully continuing the program were shown by the significance of the mean square figures at an F-test probability of $1 \%$, for all the traits considered in relation to families within sets. They indicate that there is enough genetic variability to be exploited in future cycles. In addition, they show that the objective of the program - improving the population by recurrent selection without losing genetic variability - has probably been achieved by these first two recurrent selection cycles.

The estimated mean values for the initial population, plants selected, controls and variation amplitude (maximum and minimum mean values for the family) for the population under selection showed considerable differences, especially for the main traits considered - popping and grain yield (Table 2). The existence of families with mean values higher than those of the selected fami- lies and controls, combined with the relatively high heritability and genetic gain figures, guarantee the viability of continuing with recurrent selection cycles.

The difference in the variation amplitude also indicates genetic variability in the population. Excellent results in obtaining superior materials were also reported by Pacheco et al. (1998), using the upper and lower limits for popping and grain yield to predict superior recombination in the CMS-42 and CMS-43 populations of the second recurrent selection cycle. The upper limit can rise through selection gain, which means that a maximum value detected in a given cycle can be lower than the maximum for the following cycle, and thus successively with the increase and recombination of favorable alleles in the population.

In the controls, grain yield (Table 2) was higher than both the mean of the original population and the mean of the selected families. This was expected since heterosis for grain yield in maize is widely acknowledged (Falconer, 1987; Hallauer \& Miranda Filho, 1981) and the observed inbreeding yield drop for the $S_{1}$ families is natural. However, given that the superior $S_{1}$ families will be recombined, this will restore the productive potential of the population, and there is some predicted genetic gain for yield as the most productive families are recombined, increasing the frequency of favorable alleles.

Table 2 - Estimates of the means of the original population $\left(\bar{X}_{o}\right)$, selected families $\left(\bar{X}_{s}\right)$, controls $\left(\bar{X}_{T}\right)$, lower limit $(\mathrm{LL})$ and upper limit (UL) of the populations evaluated.

\begin{tabular}{lccccccrc}
\hline Estimate & \multicolumn{9}{c}{ Traits $^{1 /}$} \\
\cline { 2 - 8 } & NDE & PE & ST & BP & PHE & NE & GY \\
\hline $\bar{X}_{o}$ & 8.870 & 13.410 & 22.740 & 7.460 & 1.750 & 18.930 & 670.74 \\
$\bar{X}_{s}$ & 7.890 & 16.300 & 23.620 & 6.810 & 1.440 & 23.960 & 950.70 \\
$\bar{X}_{T}$ & 8.524 & 12.055 & 23.584 & 8.299 & 1.835 & 26.258 & 1257.33 \\
LL & 0.00 & 3.83 & 9.00 & 0.00 & 0.00 & 2.00 & 14.00 \\
UL & 42.00 & 25.00 & 34.00 & 23.00 & 23.00 & 51.00 & 2880.00 \\
\hline
\end{tabular}

${ }^{1} / \mathrm{NDE}=$ number of diseased ears; $\mathrm{PE}=$ popping expansion; $\mathrm{ST}=$ stand; $\mathrm{BP}=$ broken plants; $\mathrm{PHE}=$ poorly hulled ears; NE $=$ number of ears; $\mathrm{GY}=$ grain yield in $\mathrm{kg} \mathrm{ha}^{-1}$.

Table 3 - Phenotypic variance $\left(\sigma_{f}^{2}\right)$, genotypic variance $\left(\sigma_{g}^{2}\right)$, residual variance $\left(\sigma^{2}\right)$, heritability on the family mean $\left(h_{x}^{2} \%\right)$ and genetic gain $(\mathrm{GG})$ estimated for the evaluated traits.

\begin{tabular}{lccccccc}
\hline \multirow{2}{*}{$\begin{array}{l}\text { Genetic } \\
\text { Parameters }\end{array}$} & NDE & PE & ST & BP & PHE & NE & GY \\
\cline { 2 - 7 } & 10.567 & 8.060 & 2.335 & 8.555 & 3.2350 & 28.580 & 25451.840 \\
\hline$\sigma_{f}^{2}$ & 4.632 & 6.680 & 1.066 & 5.809 & 2.048 & 21.968 & 21416.987 \\
$\sigma_{g}^{2}$ & 23.738 & 5.519 & 5.073 & 10.981 & 4.745 & 26.446 & 16139.407 \\
$\sigma^{2}$ & 43.85 & 82.91 & 45.71 & 67.91 & 63.37 & 76.87 & 84.15 \\
$h_{x}^{2} \%$ & -4.940 & 17.800 & 1.770 & -5.440 & -9.580 & 16.400 & 26.950 \\
GG\% & -0.219 & 1.193 & 0.201 & -0.202 & -0.083 & 1.552 & 90.380 \\
GG & & & & & & \\
\hline
\end{tabular}

${ }^{1 /} \mathrm{NDE}=$ number of diseased ears; $\mathrm{PE}=$ popping expansion; $\mathrm{ST}=$ stand; $\mathrm{BP}=$ broken plants; $\mathrm{PHE}=$ poorly hulled ears; $\mathrm{NE}=$ number of ears; $\mathrm{GY}=$ grain yield in $\mathrm{kg} \mathrm{ha}^{-1}$. 
Based on the genetic component estimates (Table 3 ), residual variance was lower than the genotypic variance for popping expansion and grain yield. In addition, these two traits presented high heritability values (above $80 \%$ ). Such results lead us to expect significant genetic gains from selection for both popping expansion and grain yield, the two most important traits in popcorn breeding.

In this study, the use of the Smith (1936) and Hazel (1943) selection index (Table 4) resulted in higher genetic gain for grain yield than for popping expansion. One explanation for the observed results lies in the economic weights assigned to individual traits. These economic weights are linked to the possibility of obtaining satisfactory gain for popping expansion (of the order of three units) while also ensuring good grain yield for the population, without which there is obviously no justification for the future release of an improved variety.

However, for both traits (popping and grain yield), genetic gains were very high, especially by comparison with the results of the first cycle of this same population. One reason for this is the type of progeny used: full-sib for the first cycle and $\mathrm{S}_{1}$ families for the second. Since additive variance is much more significant between $\mathrm{S}_{1}$ families than between full-sib families, the results are quite justifiable (Vilarinho, 2001). Another factor that helps to clarify this situation is the greater number of progenies evaluated in the second cycle, allowing a wider selection differential.

The relevance of the selection index for a popcorn breeding program was confirmed by Matta (2000) whose results also showed improvements for both popping expansion and grain yield.

The forecast for popping expansion gain in the first recombination cycle was $10.39 \%$, based on an initial mean value equivalent to an increase of 0.573 units/

Table 4 - Estimates of the original population mean $\left(\bar{X}_{o}\right)$, selected population mean $\left(\bar{X}_{s}\right)$, lower and upper limits and genetic gains $(\%)$ predicted for popping expansion (PE) and grain yield (GY) in both cycles.

\begin{tabular}{lrrrr}
\hline & \multicolumn{2}{c}{ CYCLE 1 } & \multicolumn{2}{c}{ CYCLE 2 } \\
\cline { 2 - 5 } Estimate & \multicolumn{3}{c}{ Traits } \\
\cline { 2 - 5 } & \multicolumn{1}{c}{ PE } & \multicolumn{1}{c}{ GY } & PE & \multicolumn{1}{c}{ GY } \\
\hline $\bar{X}_{o}$ & 11.04 & 1060.00 & 13.410 & 670.74 \\
$\bar{X}_{s}$ & 12.52 & 1140.00 & 16.300 & 950.70 \\
$\bar{X}_{T}$ & 11.08 & 1110.83 & 12.05 & 1257.33 \\
LI & 7.79 & 380.00 & 3.830 & 14.00 \\
LS & 15.32 & 1680.00 & 25.000 & 2880.00 \\
GG $(\%)$ & 10.39 & 4.69 & 17.80 & 26.95 \\
\hline
\end{tabular}

year (Table 4). However, after evaluating the popping mean obtained from the original population for cycle 2 , the real gain was higher, with an increase of $22.00 \%$ on the original population, representing 1.185 units/year (Table 4).

\section{CONCLUSIONS}

The effect of sets was significant for the NED, PE, BP, PHE and NE traits, confirming that the use of this source of variation is both efficient and necessary.

The effect of family within the set was also significant, showing that the genetic variability of the population is high, with the prospect of further gains in future recurrent selection cycles.

Estimates of significant genetic gains for the most important traits (grain yield and popping expansion) promise further success as the breeding program continues.

\section{REFERENCES}

ANDRADE, R.A. Cruzamentos dialélicos entre seis variedades de milhopipoca (Diallelic crossing of six popcorn varieties). Viçosa: UFV, 1996. 79p. (Dissertação - M.S.).

COIMBRA, R.R. Seleção entre famílias de meios-irmãos da população DFT1-Ribeirão de milho pipoca (Selection between half-sib families in the DFT1-Ribeirão popcorn population). Viçosa: UFV, 2000. 54p. (Dissertação - M.S.).

CRUZ, C.D. Programa Genes: Versão Windows; aplicativo computacional em genética e estatística. Viçosa: UFV, 2001. 648p.

DAROS, M.; AMARAL JR., A.T.; PEREIRA, M.G. Genetic gain for grain yield and popping expansion in full-sib recurrent selection in popcorn. Crop Breeding and Applied Biotechnology, v.2, p.339-344, 2002.

EMPRESA BRASILEIRA DE PESQUISA AGROPECUÁRIA. Recomendações técnicas para o cultivo do milho (Technical recommendations for maize cultivation). Sete Lagoas: EMBRAPA, CNPMS, 1993. 204p.

FALCONER, D.S. Introdução à genética quantitativa (Introduction to quantative genetics). 1.ed. Viçosa: UFV, 1987. 279p.

FANCELli, A.L.; DOURADO NETO, D. Produção de milho (Maize production). Guaíba: Agropecuária, 2000. 360p.

GALVÃO, J.C.C.; SAWAZAKI, E.; MIRANDA, G.V. Comportamento de híbridos de milho pipoca em Coimbra, Minas Gerais (Behaviour of popcorn hybrids in Coimbra, Minas Gerais). Revista Ceres, v.47, p.201218, 2000 .

GAMA, E.E.G.; MAGNAVACA, R.; SILVA, J.B. da; SANS, L.M.A.; VIANA, P.A.; PARENTONI, S.N.; PACHECO, C.A.P.; CORREA, L.A.; FERNANDES, F.T. Milho-pipoca (Popping maize). Informe Agropecuário, v.14, p.12-16, 1990.

HALLAUER, A.R.; MIRANDA FILHO, J.B. Quantitative genetics in maize breeding. Ames: Iowa State University Press, 1981. 468p.

HAZEL, L.N. The genetic basis for constructing selection indexes. Genetics, v.28, p.476-490, 1943.

LINARES, E. Seleção recorrente recíproca em famílias de meio-irmãos em milho pipoca (Zea mays L.) (Reciprocal recurrent selection in half-sib popcorn families). Piracicaba: USP/ESALQ, 1987. 78p. (Dissertação M.S.).

MATTA, F. de P. Seleção entre e dentro de famílias de meios-irmãos na população de milho pipoca Beija-flor (Zea mays L.) (Selection between and within half-sib families of the Beija-flor popcorn population) Viçosa: UFV, 2000. 83p. (Dissertação - M.S.). 
PACHECO, C.A.P.; GAMA, E.P.; GUIMARÃES, P.E.O.; SANTOS, M.X.; FERREIRA, A.S. Estimativas de parâmetros genéticos nas populações CMS-42 e CMS-43 de milho pipoca (Estimates of genetic parameters in CMS-42 and CMS-43 popcorn populations). Pesquisa Agropecuária Brasileira, v.33, p.1995-2001, 1998

PEREIRA, M.G.; AMARAL JR., A.T. Estimation of genetic components in popcorn based on the nested design. Crop Breeding and Applied Biotechnology, v.1, p.3-10, 2001.

SAS INSTITUTE INC. SAS user's guide: statistics. 5.ed. Cary, 1985. 958p. SMITH, H.F. A discriminant function for plant selection. Annals of Eugenics, v.7, p.240-250, 1936.
VILARINHO, A.A. Seleção de progênies endogâmicas $\mathrm{S}_{1}$ e $\mathrm{S}_{2}$ em programas de melhoramento intrapopulacional e de produção de híbridos de milho pipoca (Zea mays L.) Viçosa: UFV, 2001. 79p. (Dissertação - M.S.).

WHITTELL, G. The Times. 2002. http://www.estado.estadao.com.br/ editorias/2002/05/02/ger 011.html-29k (20 nov. 2002).

ZANETTE, V.A. Análise da variabilidade genética em variedades de milhopipoca (Zea mays L.) I. Heterose da capacidade de expansão do grão. Agropecuária Sulriograndense, v.25, p.173-181, 1989.

Received July 31, 2003

Accepted September 03, 2004 